\title{
Maritime oil freight flows to 2050: Delphi perceptions of maritime specialists
}

\author{
John Dinwoodie ${ }^{\mathrm{a}, *}$, Sarah Tuck ${ }^{\mathrm{a}}$, Patrick Rigot-Müller ${ }^{\mathrm{b}}$ \\ a Plymouth Graduate School of Management, Plymouth University, PL4 8AA United Kingdom \\ ${ }^{\mathrm{b}}$ School of Marine Science and Technology, Newcastle University, Newcastle-upon-Tyne, NE1 7RU United Kingdom
}

\section{H I G H L I G H T S}

- Local sourcing, Arctic seaways and fossil fuel intolerance lessen oil freight work.

- Oil hauls lengthen if ships re-route to avoid Emission Control Areas and piracy.

- Conservative perceptions of established specialists match early career views.

- Carbon emission reduction policies imply significantly reduced oil shipments.

- Attitude change in maritime professionals will require education and marketing.

\section{A R T I C L E I N F O}

\section{Article history:}

Received 7 June 2013

Accepted 13 August 2013

Available online 6 September 2013

Keywords:

Maritime oil freight flows

Oil shipment forecasts

Maritime specialists' Delphi survey

\begin{abstract}
A B S T R A C T
This paper aims to synthesise maritime specialists' perceptions of changing patterns of maritime oil freight flows to 2050. Debate spans published maritime oil flows globally, diverse drivers of future flows including economic growth, shipping market changes and haul lengths. A classic Delphi study to explore the perceptions of likely trends and flows to 2050 recruited a panel of early career and established maritime specialists, many with long term career commitments to this industry. Underpinned by market volatility and legislative uncertainty, the perceptions of both groups coincided and were conservative. Local sourcing, new Arctic seaways and fossil fuel intolerance will tend to reduce oil freight work but perceptions of ship re-routing to avoid for example Emission Control Areas and piracy would tend to lengthen hauls. In advanced industrial nations, reducing energy intensities and diminishing social tolerance of fossil fuels imply gradually reducing maritime oil shipments. However, to achieve radical national commitments to carbon emissions reductions will necessitate specialist education for naturally conservative maritime professionals and vigorous oil import reduction policies to curtail domestic demand for oil shipments.
\end{abstract}

\section{Introduction}

This paper aims to analyse perceptions of changing patterns of maritime oil freight flows to 2050, by synthesising the opinions of maritime specialists. It features tankers as the ship type which generates the highest total volumes of $\mathrm{CO}_{2}$ emissions (Buhaug et al., 2009), crude oil and oil products flows. Global patterns, dependent on world demand stimulated by regional surpluses and deficits, define tanker loading and discharge areas. The demand for

\footnotetext{
* Correspondence to: Plymouth Graduate School of Management, Plymouth University, Drake Circus, Plymouth, Devon PL4 8AA, United Kingdom. Tel.: +441752 585611; fax: +441752 585713 .

E-mail addresses: jdinwoodie@plymouth.ac.uk (J. Dinwoodie), stuck@plymouth.ac.uk (S. Tuck), patrick.rigot-muller@wanadoo.fr (P. Rigot-Müller).

URL: http://www.plymouth.ac.uk (J. Dinwoodie).
}

shipping crude oil and oil products derives from macro-economic demands for shipping which vary with global economic activity and the dynamic role of shipping in moving raw materials, semiprocessed or finished products in fluctuating supply chains. Because measures of demand for shipping freight work combine tonnage lifted $(\mathrm{t})$ and distance hauled $(\mathrm{km})$, changes in both affect demand in tonne-kilometres (tkm). Apparent reductions in demand for wet bulk freight work may reflect economic reversals, reducing oil intensities in production processes as technical advances require less oil to produce a given output, or shorter hauls arising from localised oil sourcing, pipeline construction or rerouting via canal upgrades.

Subject to inevitable physical measurement errors (Dinwoodie and Bhatia, 2004), global flow data emanate from official (e.g. EC, 2008) and private sources including BP's Statistical Review and Energy Outlook (www.bp.com), Exxon Mobil's Outlook for Energy 
(www.exxonmobil.com) and Shell's Energy Scenarios (www.shell. com), as do national data (e.g. EIA, 2011; DfT, 2010; Dukes, 2011; MDS Transmodal Limited, 2007). Regional surpluses and deficits of crude oil create tanker loading and discharging areas which determine the spatial patterns of 1895Mt of flows annually (Table 1; BP, 2012) with Europe, the US and increasingly South East, East and South Asia in deficit, and the Middle East Gulf (MEG), Former Soviet Union (FSU), North and West Africa, Central and South America and Canada in surplus. Although Europe, Singapore, the US and Asia Pacific regions import oil products extensively, 791 Mt traded annually (BP, 2012) engages all regions including African crude producing areas. MEG dominates oil products exports but importing regions also export following further refining. Major crude oil flows ex-MEG often route via the Cape of Good Hope or Suez Canal to Europe and the US. Suez Canal maximum sizes (Suezmax) vary with dredging, although some larger vessels transit Suez in ballast on backhauls after offloading MEG-Europe cargoes shipped fully-laden via the Cape of Good Hope, or awaiting cargoes from the SUMED pipeline. MEG also exports crude oil to India, Pakistan, Japan and China. As currently the largest single consumer and importer of oil, the US receives shipments ex-MEG and South America, including Venezuela, Brazil and Columbia, to US Gulf (USG) and US East Coast (USEC). Many movements of crude oil imports to USG and the Caribbean Sea, followed by exports of products, require lightering and transhipment at terminals which are draft restricted. Other major flows in Asia include the distribution of crude and products

Table 1

Percentage of global oil imports and exports. Source: adapted from BP (2012).

\begin{tabular}{|c|c|c|c|c|}
\hline \multirow[t]{2}{*}{ Region } & \multicolumn{2}{|l|}{ Crude oil } & \multicolumn{2}{|c|}{ Oil products } \\
\hline & Imports & Exports & Imports & Exports \\
\hline US & 24 & 0 & 15 & 15 \\
\hline Canada & 1 & 6 & 2 & 3 \\
\hline South and Central America & 1 & 11 & 12 & 7 \\
\hline Europe & 24 & 1 & 17 & 11 \\
\hline Former Soviet Union & 0 & 17 & 1 & 14 \\
\hline Middle East & 1 & 45 & 1 & 13 \\
\hline Africa & 1 & 17 & 5 & 4 \\
\hline China & 13 & 0 & 10 & 4 \\
\hline India & 9 & 0 & 1 & 5 \\
\hline Japan & 9 & 0 & 6 & 2 \\
\hline Singapore & 3 & 0 & 12 & 11 \\
\hline Other Asia Pacific & 14 & 3 & 18 & 11 \\
\hline
\end{tabular}

ex-FSU to Continental Europe, and onward to USG/USEC. Refineries in Singapore, Malaysia and the Philippines which export products are supplied by crude imports from Indonesia and MEG. Indonesia also exports crude oil and gas to China, Japan, Singapore, and Korea. In the Mediterranean and Black Sea area, crude oil flows ex-FSU, Libya and Algeria, and Iraqi oil transfers through Ceyhan terminal in Turkey. Product cargoes flow ex-Italy, Spain and France.

Tanker flows remain relatively concentrated but increasing ship sizes (Lindstad et al., 2012) have necessitated more offshore terminal developments of loading and discharging facilities which may include floating storage vessels to release land for refining. In the North Sea and elsewhere, offshore oil production generates offshore transfers from production vessels or an undersea oil production facility. Accumulated atmospheric emissions from tankers queuing to enter ports near urban areas may influence decisions to establish Emissions Control Areas (ECA; IMO, 2013).

Reviews identified eight key drivers of maritime tanker demand (D1...D6). Demand estimates (D1) vary inter alia with demand for total freight transport, dependant on: population and Gross Domestic Product (GDP) growth, production and location decisions; sensitivity to shipping costs including bunker prices (D2) which influence routing (D3) and maritime mode shares (D4); sourcing policies; and haul lengths (D5-D6; Stopford, 2009). The paper reviews these drivers before discussing the methodology and results of a classic Delphi survey of expected likely trends in tanker freight flows to 2050. Discussion notes that although volatile markets, behavioural uncertainties and prospective legislation explain conservative predictions which imply a business as usual philosophy, vigorous carbon emissions reduction policies may supersede gradual behavioural trends towards fossil fuel reduction.

\section{Drivers of maritime oil flows}

\subsection{Some drivers and forecasts of future demand}

Oil freight flows vary with the supply and demand for crude oil and oil products, which depend on the demand for transport, traditionally related to GDP. Predictions of when oil demand will peak include "by 2020" if links with GDP are weak (Aleklett et al., 2010); "likely by 2030, with a significant risk pre-2020" (Sorrell et al., 2010); "post-2020", in Shell's (2008) Scramble scenario in which climate shocks necessitate oil substitution; and "post-2040"

Table 2

Selected forecast changes (CAR) Source: adapted from the source stated.

\begin{tabular}{|c|c|c|c|c|c|c|c|}
\hline Area, variable, scenario & $\begin{array}{l}\text { From } \\
\text { To }\end{array}$ & $\begin{array}{l}2010 \\
2015\end{array}$ & $\begin{array}{l}2015 \\
2020\end{array}$ & $\begin{array}{l}2020 \\
2025\end{array}$ & $\begin{array}{l}2025 \\
2030\end{array}$ & $\begin{array}{l}2030 \\
2040\end{array}$ & $\begin{array}{l}2040 \\
2050\end{array}$ \\
\hline Global & Source & & & & & & \\
\hline Oil consumption: scramble & Shell, 2008 & 0.57 & 0.57 & -0.38 & -0.38 & -1.06 & -1.19 \\
\hline Oil consumption: blueprints & Shell, 2008 & 0.79 & 0.79 & 0.05 & 0.05 & -0.26 & -1.60 \\
\hline Oil production & $\mathrm{BP}(2012)$ & 0.89 & 0.89 & 0.58 & 0.58 & & \\
\hline Oil consumption & $\mathrm{BP}(2012)$ & 0.61 & 0.61 & 0.38 & 0.38 & & \\
\hline Oil consumption & EM, 2012 & 1.00 & 1.00 & 1.00 & 0.40 & 0.40 & \\
\hline GDP non-OECD & EM, 2012 & 5.00 & 5.00 & 5.00 & 3.80 & 3.80 & \\
\hline \multicolumn{8}{|l|}{ Europe } \\
\hline EU GDP & EM, 2012 & 1.90 & 1.90 & 1.90 & 1.60 & 1.60 & \\
\hline Europe/Eurasia oil consumption & $\mathrm{BP}(2012)$ & -0.14 & 0.00 & -0.04 & -0.15 & & \\
\hline Europe/Eurasia oil production & $\mathrm{BP}(2012)$ & -0.10 & -0.08 & -0.14 & -0.06 & & \\
\hline OECD Europe & EIA (2011) & -1.08 & -0.77 & -0.32 & 0.05 & 0.16 & \\
\hline \multicolumn{8}{|l|}{ Oil consumption, base case } \\
\hline Low oil price & EIA (2011) & -0.02 & 0.19 & 0.19 & 0.41 & 0.41 & \\
\hline High oil price & EIA (2011) & -1.77 & -1.25 & -1.25 & -0.05 & -0.05 & \\
\hline OECD Europe conventional production, base case & EIA (2011) & -4.55 & -3.15 & -1.13 & -0.37 & 0.31 & \\
\hline
\end{tabular}


in ExxonMobil's model where GDP growth in developing countries escalates demand (www.bp.com; www.exxonmobil.com) (Table 2). By 2030, Lloyd's Register (2013) estimate that oil demand in China will be triple US demand in 2011. At supra-national scales, base case estimates of 2.0\% Compound Annual Rate (CAR) real GDP growth for OECD Europe to 2030 range from 1.6\% with low growth to $2.5 \%$ with high growth (EIA, 2011). Longer term forecasts predict reducing European GDP growth and energy consumption and EU demand for freight transport decoupling from GDP growth as economies dematerialise and populations stagnate. European oil production will decline (EC, 2008; EIA, 2011). Hammer (2009) observed that global oil tanker tonnage in 2008 was unchanged since 1978 but will this continue (D1a, D1b)? Future changes in oil intensity, which measures oil used per unit of output and has halved in industrial nations in 30 years, are also debateable (D1c, D1d; Osler 2010).

Within Europe, predicted 9\% CAR base case declines in UK North Sea oil production (DTi, 2007) will diminish GB crude oil exports and raise imports (MDS Transmodal, 2007), but rates will vary with investment and taxation policy (Nakhle, 2007). Tonnages shipped ashore will decline but maritime market shares will rise as fewer pipeline networks serve increasingly remote small oil field developments. Indeed, carbon storage in redundant North Sea oilfields may generate new ship movements if technically robust low-emission vessels develop to transport captured carbon emerge (Mander et al., 2012). The UK Stern Review linked per capita GDP with $\mathrm{CO} 2$ emissions and proposed a hypothetical relationship between income and local pollutants, defined by environmental Kuznets curves. Beyond a certain point, rising per capita incomes stimulate local abatement incentives and appropriate political and regulatory mechanisms to control pollutants (Her Majesty's Treasury, 2006, p. 191). Eventually declining energy intensities will reduce oil demand in Western Europe (EC, 2008), as may perceptions of speculative Kuznets curve behavioural effects as intolerance to fossil fuels grows (Verbruggen and $\mathrm{Al}$ Marchohi, 2010).

\subsection{Bunker prices and shipping market changes}

Principles underpinning the economic analysis of shipping markets are well documented (Stopford, 2009) and sectoral models of particular ship types (Glen, 2006) now predominate. Specialist markets and devices designed to manage extensive operational risks including pooling agreements (Gilje et al., 2002) and hedging instruments (Dinwoodie and Morris, 2003) testify to the volatility of oil supply chains. Estimates of the long and short run impacts of bunker price changes on maritime freight rates (D2a, D2b) underpin numerous maritime policies. Given that shipping costs comprise only $4 \%$ of crude oil import values (Korinek and Sourdin, 2009), worldwide demand for maritime transportation of oil and freight rates have been relatively inelastic to bunker price changes (UNCTAD, 2010). Similarly any potential to cut shipping emissions using market-based reduction measures including bunker levies (Miola et al., 2011) depends on freight rate to bunker price elasticities, which if high, would favour local sourcing, pipeline transportation and reduced demand for maritime transportation.

Perceptions of how particular developments in ships and shipping markets will affect total demand are crucial. As climate change heightens drought risks, will more tankers be deployed as water carriers (D3a; Hammer, 2009)? Similarly, how will shortened sea routes arising from Arctic ice-melt (D3b, D3c; Ho, 2010) or an enlarged Panama Canal (D3d, D3e; Stott and Wright, 2012) impact demand for tanker freight work? Regulations now underpin ship design to encourage improvements in new ship fuel consumption, after the International Maritime Organisation (IMO) introduced an Energy Efficiency Design Index (EEDI; IMO, 2013; MEPC.1/Circ.681) specifying minimum levels and promoting ongoing technical development by enabling a comparison between similar individual ships. How will a mandatory baseline index to provide a transparent basis for comparison, regularly updated to reflect technological changes, affect maritime transportation (D3f, D3g)? Also, how will rising demand for new fuels including LNG and nuclear power affect total tanker demand (D3h, D3i)?

Future demand for wet bulk maritime transportation will also depend on perceptions of how pipeline investments will impact oil import mode splits as more pipelines link Canadian tar sands with the US (D4a, D4b), Russian and MEG oilfields with Europe (D4c, D4d), and MEG and Russian oilfields with China (D4e, D4f; Hammer, 2009).

\subsection{Haul lengths}

If rising bunker costs induce localised or regionalised oil sourcing with shortened supply chains, global average maritime haul lengths will reduce (D5a; Hammer, 2009). Further, regulations which influence the type of fuel that ships may consume in particular areas and undefined future ECA designations could promulgate ship re-routing to avoid them (D5b, D5c). A 1973 International Convention for the Prevention of Pollution from Ships was modified by IMO Protocol in 1978, creating MARPOL 73/78. In 1997, Annex VI, Regulations for the Prevention of Air Pollution from Ships, was adopted. Enforced in May 2005 this regulated the mass/mass of sulphur content for marine fuel oil to control sulphur oxide (SOx) emissions from ships (IMO, 2013). Sulphur ECAs in the North Sea, Baltic Sea and North America costeffectively cut ship-originated air pollution (Wang and Corbett, 2007) and were extended to include other emissions, but future developments and their impacts remain unknown. To reduce carbon emissions, an Energy Efficiency Operational Index (EEOI) for ships in operation compares the energy efficiency $\left(\mathrm{CO}_{2}\right.$ per $\mathrm{tkm}$ ) of a specific ship against others of its type. A Ship Energy Efficiency Management Plan (SEEMP) incorporates best practice relating to voyage planning, optimal speed (Lindstad et al., 2011), power and handling, cargo handling and fleet and energy management. The EEOI and SEEMP imply shorter hauls to reduce freight work (D5d, D5e; IMO, 2013). However, multi-sourcing strategies to ensure secure energy supplies may also imply changed haul lengths (D5f).

Useful indicative specialist perceptions of changing specific average haul lengths include the effects of Arctic ice-melt in creating Northwest (NW) and Northeast (NE) passages on routes such as NE Asia-W. Europe (D6a, D6b, Parsons et al., 2011; Ho, 2010) or an enlarged Panama Canal on NE Asia-US E. Coast routes (D6c, D6d; Stott and Wright, 2012). Conversely, if droughts induced by climate change create more failed states and foster piracy, suboptimal routing to avoid trouble spots may lengthen maritime hauls (D6e; Osler, 2010).

\section{Methodology}

\subsection{Study design}

Secondary maritime commodity flow data proved insufficient to investigate debateable issues, being either unavailable or incomparable (Glen and Marlow, 2009). Changing classifications in aggregate trade flow data frustrated serial commodity comparisons, where official UK oil products flow data incorporated liquefied gas until 2000 (DfT, 2010). Different spatial aggregations frustrate comparisons of data collated for Great Britain (GB) and the UK (MDS Transmodal Limited, 2007; DECC, 2009; DfT, 2010). 
Changing trading boundaries associated with EU expansion compound problems. Tracking and apportioning flows is problematic as vessel output measures span movements in national waters, number of vessel arrivals and tonnes loaded at national ports (Gilbert and Bows, 2012). Port commodity arrivals data which typically fails to identify transhipment flows or an ultimate source or destination hampers flow reporting. Accordingly, the drivers of future tanker demand (D1:D6) were evaluated via research strategies such as canvassing specialists to build consensus rather than forecasts based on scenarios of future developments, extrapolation of past trends and analysis of historical patterns (Stopford, 2009; Saaty and Boone, 1990). Longer term forecasts often deploy scenario constructions built on opinion surveys (Petersen et al., 2009; Schiffer, 2008; Lloyd's Register, 2013; Mander et al., 2012). However, because this study aims to synthesise the perceptions of maritime specialists it requires a technique to facilitate group evaluations of statements rather than the construction of scenarios. Delphi techniques are apposite because they facilitate remote communication between panellists who are recruited to represent key viewpoints (Linstone and Turoff, 1975) typically following literature reviews which generate sets of initial statements. Panellists' evaluations of statements and their responses are iteratively fed back until consensus emerges.

This study sought to canvas specialists' opinions and synthesise their perceptions of future demand for wet bulk shipping flows to 2030 and 2050. Stakeholder views span the owners, managers and operators of ships; managers of ports, logistics and supply chain systems; brokers, consultants, classification societies, insurers and regulators. As a holistic interconnected system, international shipping is too complex for one individual to comprehend and individual stakeholder experiences uniquely colour conceptualisations of emerging trends and prospects. To achieve study objectives by canvassing and probing specialists' perceptions of emergent issues requires a survey technique capable of generating consensus. Furthermore, rapid change, uncertainty and complex multifaceted implementation issues necessitate a multidisciplinary perspective which engages diverse knowledgeable experts. A Delphi panel offers a structured technique which assists researchers to understand the implications of changing operational environments, and empowers stakeholders to communicate.

Delphi questioning facilitates asynchronous responses and can accommodate geographically dispersed participants, including an international panel. Aside from forecasting, applications suit gathering data to explore logistics planning and potential policy options (Linstone and Turoff, 1975; Cetin and Cerit, 2010; Makukha and Grey, 2004; von der Gracht and Darkow, 2010). Applications to energy policy include hybrid and mixed methods studies (Tavana et al., 2012; LaBelle, 2012) and focus on divergent opinions (Makkonen et al., 2012). However, an objective of synthesising perceptions suits a "Classic" design to canvass opinions and achieve consensus, varied slightly to process numerical data. Delphi designs typically aim to ensure anonymity, controlled feedback, iteration and participating experts (Linstone and Turoff, 1975; Nowack et al., 2011; Landeta, 2006). Each panellist remains anonymous to deny intra-panel communication and prevent any bandwagon effects whereby one individual or viewpoint may dominate or influence others. In this design, the mean response on each statement was fed back to panellists who were offered an opportunity to revise their initial evaluation. To tap specialist expertise a Delphi panel was established to explore controversial issues (D1:D6). The processes whereby the Delphi instrument was derived, how panellists were selected, and the administration and analysis of two rounds of Delphi (R1, R2) are considered next.

\subsection{The Delphi instrument}

In this study, which is replicable, assurances of the internal validity of the content, constructs and criteria deployed match considerations of generalisability and external validity. Statements in the Delphi instrument derived from the trade-press ensured content-coincidence with the object of study. However, because panellists did not generate these Delphi statements and the validity of the constructs evaluated is not grounded in their expertise, all statements offered an "unable to comment" option. This also ensured that participation was voluntary. To ensure criterion validity statements must correlate with an evaluation, which may be compromised by high drop-out rates. To enhance their awareness of this, R2 panellists were informed that nonreturn would be assumed to represent confirmation of their initial choices. Regarding external validity, although panellists' perceptions are inevitably influenced by contemporary events, shortterm market distortions have limited influence on long-term perceptions (Piecyk and McKinnon, 2010). Aside from this, recruitment of a committed panel of diverse stakeholders embracing multiple nationalities and disciplinary interest maximises the likelihood of achieving generalisability.

Recent shipping trade press articles which discussed issues driving maritime oil flows (Dinwoodie et al., 2011) were refined into draft statements (D1:D6). Eight shipping academics in four universities specialising in engineering, logistics, geography, management and economics, tested their suitability for inclusion in a Delphi survey. If feasible to canvass, the academics sought splitperiod quantitative perceptions of developments 2010-2030 (“ $\alpha$ "), and from 2030 to 2050 (" $\beta$ ") rather than 2010-2050 (" $\eta$ "). Further, given a 2050 perspective, they recommended a panel comprised of substantial proportions of early career specialists with reasonable expectations of maintaining long term industrial commitments, to minimise non-commitment bias (Fowkes and Preston, 1991). Following further refinements a pilot Delphi panel was convened to test a draft online Qualtrics software survey instrument. On many questions, panellists were offered modified Likert scales incorporating an 'unable to comment' option to respond to quantitative statements about their perceptions of developments

Table 3

Response levels and assumed midpoints.

\begin{tabular}{|c|c|c|c|c|c|c|}
\hline Question & Score & 1 & 2 & 3 & 4 & 5 \\
\hline \multirow[t]{2}{*}{ D1,D2 } & Level & $>50 \%$ Too high & $25-50 \%$ Too high & About right & $25-50 \%$ Too low & $>50 \%$ Too low \\
\hline & Midpoint & 0.60 & 0.73 & 1.00 & 1.37 & 1.67 \\
\hline \multirow[t]{2}{*}{ D3 } & Level & Fall > 20\% & Fall $10-20 \%$ & Change little & Rise $10-20 \%$ & Rise $>20 \%$ \\
\hline & Midpoint & 0.70 & 0.85 & 1.00 & 1.15 & 1.30 \\
\hline \multirow[t]{2}{*}{ D5,D6 } & Level & $>25 \%$ shorter & $10-25 \%$ Shorter & Little changed & $10-25 \%$ Longer & $>25 \%$ Longer \\
\hline & Midpoint & 0.70 & 0.83 & 1.00 & 1.175 & 1.30 \\
\hline \multirow[t]{2}{*}{ D4 } & Level & Fall > 50\% & Fall 25-50\% & Change little & Rise $25-50 \%$ & Rise $>50 \%$ \\
\hline & Midpoint & 0.60 & 0.73 & 1.00 & 1.37 & 1.67 \\
\hline
\end{tabular}


in $\alpha$ and $\beta$. In pilot surveys, several incomplete responses connoted a shorter instrument and widespread non-response to $\beta$ questions necessitated merged $\eta$ comparisons. Questions to estimate voyage lengths explicitly requested estimates "averaged over all relevant routes, ship sizes and types." To estimate tonnages, elasticities and proportions, operationally relevant groupings within 25,50 and $67 \%$ of a central estimate were canvassed, reduced to 10,20 and $30 \%$ for global demand, and 10, 25 and 35\% for voyage length estimates. Using these indicative class intervals to generate assumed midpoints (Table 3 ) to facilitate computation of mean estimates, mean $\alpha=1.07$ on question 1, a statement that tonnage would remain unchanged, was considered $7 \%$ too low, implying anticipated 7\% tonnage growth to 2030 .

\subsection{Panel selection}

To ensure content validity, Delphi panels should incorporate knowledgeable and interested specialists who represent multidisciplinary stakeholder interests and viewpoints (Czinkota and Ronkainen 1997; Qu et al., 2010). With a 2050 planning horizon the study explicitly recruited specialist practitioners (group A), or early career specialist postgraduates in shipping, logistics and supply-chain management (group B), most with prior relevant industrial experience and all with recent experience in compiling reports investigating the complex and interrelated drivers of bulk shipping demand (Alberts, 2007). Importantly, group B would be instrumentally and industrially committed long-term towards 2050. Diverse panellists' interests further enhanced the content validity of the study, given that all participants were knowledgeable about wet bulk shipping. Panel membership by invitation only avoided any self-selection bias. Invitations to participate in Group A were emailed to 51 heads of either wet bulk or research at shipping organisations listed in membership pages of the Institute of Chartered Shipbrokers, plus 15 personal contacts, to widen representation; five responded fully to the online R1 survey. After some questions requesting $\beta$ estimates were removed, follow-up reminders in early 2012 generated six further responses. Invitations to join group B were emailed to 85 specialists in December 2011 and following repeat invitations 24 completed the R1 instrument to supplement 11 practitioners. An overall joint invitation to participation rate of 4.3 (23\%), closely matches average rates (Nowack et al., 2011).

Practitioner panellists included two consultant marine researchers, a senior marine planner in a petroleum company, managing director of an oil credit broker, manager of oil projects in a major oil company, a senior oil credit analyst, one shipping company managing director and one chief executive, a senior market analyst, a classification society specialist, and a tanker segment manager. When combined with Group B's specialist interests, industrial experiences spanned procurement to logistics, and panellists' professional interests embraced most wet bulk shipping specialisations (Table 4), three continents, and experience of most professional interests and ship sizes.

\subsection{Data collection and analysis}

Invitations to participate were emailed because this method is flexible, convenient and empowers response when convenient to the recipient. Following two reminders, 35 R1 responses received by March 2012 were analysed. To ensure credibility, personalised R2 questionnaires were compiled, incorporating the individual's $\mathrm{R} 1$ response, mean response and an invitation to respond finally alongside an emboldened statement that non-return would be presumed to represent confirmation of initial choices. These were emailed to R1 respondents either as MS Word attachments or an invitation to return an individualised Qualtrics questionnaire.
Table 4

Profile of Delphi panellists.

\begin{tabular}{lll}
\hline Characteristic & Group & $\begin{array}{l}\text { Percentage of } \\
\text { panellists }\end{array}$ \\
\hline \multirow{2}{*}{ Nationality } & Asia & 34 \\
& Non-UK Europe & 34 \\
& UK & 22 \\
& Africa & 10 \\
Main professional interest & Miscellaneous supply & 35 \\
& chain & \\
& Logistician & 31 \\
& Researcher & 19 \\
& Government or & 6 \\
& regulation & \\
& Ship owner & 3 \\
& Port manager & 3 \\
& Shipbroker & 3 \\
Ship size currently engage & Various & 48 \\
with & Suezmax & 29 \\
& Very large & 11 \\
& Panamax (2011) & 6 \\
& Handysize & 6 \\
\hline
\end{tabular}

Following two reminders, 14 R2 responses received during March were analysed, with 11 showing changes, an acceptable rate given the explicit presumption that non-response represents continued participation. Results are tabulated thematically (Tables 5-8) to show R1 and R2 mean scores and the percentage fall in standard deviation (s.d.) observed on all but four statements, which testifies to increased consensus in $\mathrm{R} 2$.

The preferred statistic to test for differences in the central tendency of the distributions of responses between various subgroupings was a non-parametric independent samples MannWitney $U$-test. This statistic was selected because although visual inspection of the histograms and normal Q-Q probability plots for each variable for all sub-groups typically suggested normal distributions, several variables exhibited some skewness. Non-parametric comparisons were preferred, because although inferential power is slightly reduced, this treatment ensured consistency across all variables. Because comparisons between Groups A and B revealed a statistically significant difference $(p<0.05)$ only on D1a (Table 5$)$ no further disaggregation was undertaken. A further test for consistency between early and late respondents compared the first quartile of early responses with the last quartile. Because late respondents had been sent additional reminders, they may exhibit characteristics similar to those of non-respondents (Piecyk and McKinnon, 2010). However, a statistically significant difference $(p<0.05)$ between early and late respondents on only one R1 variable, and none in R2 indicated that non-response bias is unlikely.

\section{Results}

\subsection{Perceived growth and tanker demand}

Demand estimates for wet bulk shipping revealed that following unchanged global tonnage since 1978, mean considered responses anticipated limited growth $(\alpha=7 \%, 0.34 \%$ CAR; $\beta=4 \%$, $0.195 \%$ CAR). If the oil intensity of production in developed economies continues to halve in 30 years, $(-2.29 \%$ CAR; Osler, 2010 ) then by 2030 current output levels would require $63 \%$ of 2010 oil consumption compared with panellists' considered estimates of $64.4 \%$ ( $\alpha=-2.176 \%$ ) reducing to $40.9 \%$ ( $\beta=-2.241 \%$ CAR) by 2050 . If panellists are correct, given comparable current oil consumption totals in OECD and non-OECD economies, 2010 
Table 5

Freight demand and rates elasticity estimates.

\begin{tabular}{|c|c|c|c|c|}
\hline Response scores: & No reply & Mean & Mean & \% Fall in s.d. \\
\hline $1=>50 \%$ too high; $2=25-50 \%$ too high; $3=$ about right; $4=25-50 \%$ too low $5=>50 \%$ too low. & & $\mathrm{R} 1$ & $\mathrm{R} 2$ & \\
\hline D1a. Global wet bulk tonnage will remain unchanged 2010-2030. & 2 & 1.08 & 1.07 & 8 \\
\hline D1b.... and in 2030-2050 & 5 & 1.06 & 1.04 & 4 \\
\hline $\begin{array}{l}\text { D1c. The quantity of oil used in each unit of industrial output in developed economies } \\
\text { will halve in } 30 \text { years pro rata from } 2010 \text { to } 2030\end{array}$ & 0 & 0.96 & 0.95 & 13 \\
\hline D1d. ... and in 2030-2050 & 3 & 1.02 & 1.03 & 10 \\
\hline \multicolumn{5}{|l|}{ D2. How accurate are the following estimates of wet bulk freight rates changes in relation to bunker price changes? } \\
\hline D2a. In the long run the spot freight rate for oil will rise $20 \%$ if bunker fuel prices double in real terms & 4 & 1.10 & 1.08 & 12 \\
\hline D2b. In the short run the spot freight rate for oil will rise $20 \%$ if bunker fuel prices double in real terms & 4 & 0.98 & 0.96 & 4 \\
\hline
\end{tabular}

\section{Table 6}

Drivers of global demand.

\begin{tabular}{|c|c|c|c|c|}
\hline Response scores: & No reply & Mean & Mean & $\%$ Fall in s.d. \\
\hline $1=$ fall $20+\% ; 2=$ fall $10-20 \% ; 3=$ change little; $4=$ rise $10-20 \% ; 5=$ rise $20+\%$ & & R1 & $\mathrm{R} 2$ & \\
\hline D3a More demand for water carriers will cause tkm from 2010 to 2050 to: & 2 & 1.11 & 1.11 & 2 \\
\hline D3b. Shorter sea routes due to Arctic ice-melt will cause tkm 2010-2030 to: & 0 & 0.97 & 0.98 & 4 \\
\hline D3c ....and 2030-2050? & 2 & 1.00 & 1.00 & 4 \\
\hline D3d. An enlarged Panama canal will cause tkm 2010-2030 to: & 1 & 1.02 & 1.03 & 7 \\
\hline D3e ... and 2030-2050? & 2 & 1.00 & 1.03 & 11 \\
\hline $\begin{array}{l}\text { D3f. IMO Energy Efficiency Design Index regulations which require ships to } \\
\text { emit less carbon will cause tkm 2010-2030 to: }\end{array}$ & 1 & 0.94 & 0.95 & 9 \\
\hline D3g... and 2030-2050? & 3 & 0.93 & 0.94 & 0 \\
\hline D3h Rising demand for LNG will cause tkm 2010-2050 to: & 2 & 1.05 & 1.04 & 3 \\
\hline D3i. Changed demand for nuclear power will cause tkm 2010-2050 to: & 3 & 0.95 & 0.96 & 10 \\
\hline
\end{tabular}

Table 7

Some modal split estimates.

\begin{tabular}{|c|c|c|c|c|}
\hline Response scores: & No reply & Mean & Mean & $\%$ fall in s.d. \\
\hline $1=$ fall $50+\% ; 2=$ fall $25-50 \% ; 3=$ change little; $4=$ rise $25-50 \% ; 5=$ rise $50+\%$ & & $\mathrm{R} 1$ & R2 & \\
\hline $\begin{array}{l}\text { D4a. Oil pipelines linking the US to Canadian tar sands, will cause the \% of US oil imports moved } \\
\text { in ships from } 2010 \text { to } 2030 \text { to: }\end{array}$ & 0 & 0.93 & 0.93 & 6 \\
\hline D4b...and 2030-2050? & 2 & 0.87 & 0.88 & 7 \\
\hline $\begin{array}{l}\text { D4c. More oil pipelines from MEG to Europe and Russia will cause the \% of European oil imports } \\
\text { moved in ships 2010-2030 to: }\end{array}$ & 0 & 0.98 & 0.96 & 10 \\
\hline D4d...and 2030-2050? & 2 & 0.94 & 0.92 & 13 \\
\hline D4e. More oil pipelines from MEG to China and Russia will cause the \% of China's oil imports moved in ships $2010-2030$ to: & 1 & 1.00 & 0.96 & 14 \\
\hline D4f... and 2030-2050? & 3 & 0.97 & 0.96 & 16 \\
\hline
\end{tabular}

\section{Table 8}

Voyage length estimates.

D5. How will solely the driver shown affect the global average voyage length of wet bulk hauls ( $\mathrm{km}$ )?

Response scores: $1=25+\%$ shorter; $2=10-25 \%$ shorter; $3=$ little changed; $4=10-25 \%$ longer; $5=25+\%$ longer

$\begin{array}{lllr}\begin{array}{l}\text { No } \\ \text { reply }\end{array} & \text { Rean } & \text { Mean } & \text { R2 Fall in s.d. } \\ 3 & 0.94 & 0.93 & 17 \\ & & & \\ 2 & 1.01 & 1.01 & 14 \\ 4 & 0.99 & 0.97 & 20 \\ 2 & 0.97 & 0.95 & 17 \\ 3 & 0.96 & 0.96 & 13 \\ 2 & 0.97 & 0.96 & 10 \\ & & & \\ 5 & 0.87 & 0.85 & 9 \\ & & & \\ 5 & 0.85 & 0.83 & 11 \\ 3 & 0.92 & 0.92 & 7 \\ 5 & 0.94 & 0.93 & 17 \\ 4 & 1.06 & 1.05 & 5\end{array}$

D5a. Rising bunker costs by favouring sources close to demand locations will cause global average tanker hauls (km) 2010-2050 to be:

D5b. More Emission Control Areas may induce ship re-routing to avoid them, causing hauls (km) 2010-2030 to be:

D5c ... and in 2030-2050?

D5d. Ocean Routing and operating measures to reduce carbon emissions, will cause hauls (km) 2010-2030 to be:

D5e ... and in 2030-2050?

D5f. Multi-sourcing to ensure secure energy supplies, will cause hauls (km) 2010-2050 to be:

D6a. Due to a Canadian NW Passage created by Arctic ice melt, average voyage lengths NE Asia-West Europe (km) 2010-2050 will be:

D6b. Due to a Russian NE Passage arising from ice melt, average NE Asia- West Europe voyage lengths (km) 2010-2050 will be: D6c. Due to an enlarged Panama Canal, NE Asia-USEC voyage lengths (km) averaged over all routes used 2010-2030 will be: D6d...and in 2030-2050?

D6e. Due to ship re-routing to avoid piracy caused by droughts and failed states, voyage lengths (km) NE Asia-West Europe averaged 4 over all routes 2010-2050 will be: 
global oil consumption could satisfy a $250 \%$ increase in industrial output in developing economies to 2050 . However, ceteris paribus, with expected energy intensity reducing quicker in non-OECD economies $(\eta=-2.9 \%$ CAR) than in OECD economies $(\eta=-2.1 \%$ CAR, EM, 2012) current oil consumption levels could support trebled output in developing economies by 2050.

\subsection{Bunker price and shipping market changes}

Regarding the impact of bunker price changes on wet bulk freight rates, considered mean panel estimates of the short run spot freight rate elasticity for oil in relation to doubled real bunker fuel prices imply $19.2 \%$ reduction in demand. Coupled with a long run elasticity estimate of 0.216 these findings imply a tanker market relatively unresponsive to bunker price changes. Market based measures to influence shipping emissions would be relatively ineffectual in both the short and long term. Very substantial bunker fuel levies would be required to significantly impact freight rates, even ignoring cost pass-through effects to import and final market prices. However, if operators could not avoid bunker fuel levies, they offer policy makers high revenue-raising potential.

Expectations of increased total global wet bulk freight work attributable solely to increased demand for water carriers $(\eta=11 \%$, Table 6) and an enlarged Panama Canal ( $\alpha=3 \%, \beta=3 \%)$ are logical. Counter-intuitive increases attributed to rising demand for LNG $(\eta=4 \%)$ are best discarded, as panellists probably assumed that "tanker flows" embraced liquid gas carriage, omitted here. Tanker freight work reductions due to EEDI regulations $(\eta=-11 \%)$, nuclear power $(\eta=-4 \%)$ and shorter Arctic sea-routes $(\alpha=-2 \%)$ imply neutral net effects from the drivers listed.

Panellists expected oil pipelines to increasingly reduce the proportions of US oil imports moved in ships $(\alpha=-7 \%$, $\beta=-12 \%$, Table 7 ) as oil pipelines link the US to Canadian tar sands. The expected proportion of European oil imports moved in ships would reduce, due to more MEG-Europe MEG-Russia oil pipelines ( $\alpha=-4 \%, \beta=-8 \%$ ). Oil pipelines MEG-China and MEGRussia will also reduce the proportion of China's oil imports moved in ships ( $\alpha=-4 \%, \beta=-4 \%$ ).

\subsection{Haul lengths}

Taken individually, no single driver was perceived as radically impacting voyage lengths globally but cumulatively, their impacts would mount. By 2050, predicted shortening of tanker haul lengths to counter rising bunker costs $(\eta=-7 \%$, Table 8$)$, ocean routing $(\eta=-9 \%)$, multi-sourcing to ensure secure energy supplies $(\eta=-4 \%)$ and initial possible ECA-avoidance followed by later acceptance $(\eta=-2 \%)$ imply cumulative reductions of $22 \%$. Drivers affecting specific average voyage lengths included N.E. Asia-W. Europe hauls shortened by a Canadian N.W. Passage created by Arctic ice melt $(\eta=-15 \%)$ and a Russian N.E. Passage $(\eta=-17 \%)$. An enlarged Panama Canal shortens hauls $(\alpha=-8 \%$, $\beta=-6 \%$ ) but ship re-routing to avoid piracy caused by droughts and failed states would lengthen N.E. Asia-W. Europe hauls $(\eta=5 \%)$.

Interestingly, work published after these Delphi surveys commenced (Mander et al., 2012) estimated that in 2006 oil and oil products generated $34 \%$ of UK shipping's freight work but $68 \%$ of UK $\mathrm{CO}_{2}$ emissions, explained by oil products transport in smaller fuel-inefficient ships which require auxiliary boilers to keep cargoes viscose. Although the Delphi surveys reported did not consider the size of ship deployed, or focus explicitly on their emissions, binding obligations to reduce $\mathrm{CO}_{2}$ emissions made outside the maritime sector may impact it very significantly. Commitments to $80 \%$ reductions by 2050 imply radical strategies to realise them which include decarbonisation scenarios focused on "higher carbon capture and storage" or more bioenergy renewables based on "higher energy efficiency, more renewable energy" (Department of Energy and Climate Change, 2011). Both imply dramatic reductions in shipping freight work by 2050 with shipment of biofuels rather than fossil fuels, although some oil imports remain (Mander et al., 2012). CCC central estimates show UK domestic crude inward oil shipments reducing from $33 \mathrm{Mtpa}$ in 2006 to 7 Mtpa in 2050, imports reducing from 43 to 12 Mtpa, domestic petroleum products movements reducing from 13 to 3 Mtpa and imports from 35 to 18 Mtpa.

The maritime industry is notoriously conservative, which may explain the conservative Delphi expectations of business as usual reported above. However, if national commitments to emissions reduction are to be realised (Committee on Climate Change(CCC), 2011; Mander et al., 2012) or to guide other states, critical policy issues relate to how quickly and effectively energy officials can transform fossil fuel intolerance and reducing energy intensities into acceptable policies to achieve ambitious emissions commitments. For example, after 2016, much demand for heavy marine fuel oils will shift to middle distillates due to MARPOL Annex VI regulations on marine fuel (IMO, 2013). However, to achieve UK shipping carbon emissions targets by 2050 will require radical combinations of supply chain network optimisation, social and industrial advances, and major technical advances in ship design, management and operation.

\section{Discussion and conclusion}

Delphi studies potentially share criticisms which taint most behavioural forecasts (Stopford 2009, 739). To discourage respondents from offering precise but wrong answers which might appear more authoritative than vague right answers, this work offered no precise response categories. Similarly recruitment of a panel incorporating many early career specialists reduced the likelihood of status quo bias whereby responses may be coloured by implicit assumptions that past trends and institutional frameworks will endure. To avoid replication of herding instincts observed in shipping cycles which drive optimism during peaks and pessimism during troughs, panellists were offered no statements about short term developments. If all panellists are uncertain, similar predictions may arise creating apparent but incorrect consensus. Interestingly, the perceptions of early career specialists mirrored those of established specialists, and both were very conservative compared with recent UK energy policy proposals (CCC, 2011). This implies that to achieve ambitious energy objectives will also require extensive education, publicity and possibly market interventions targeting both early career and established maritime professionals to inform, coax and persuade them away from Business As Usual expectations. To target career entrants, advanced education in maritime business and related disciplines could usefully feature case studies including extreme scenarios requiring zero carbon emissions. Action research cases which require participants to ponder and formulate operational responses to extreme policy restraints should embrace the implications of accelerated carbon reduction policies. To better inform experienced maritime practitioners about policy developments and future prospects requires targeted and effective dissemination of regular factsheets from national governments and supra-national bodies such as IMO.

In this research, if conservative opinions do imply universal uncertainty, this phenomenon endorses the complexities of long term forecasting in volatile markets. Policy makers must heed this volatility before imposing for example ad valorem levies to reduce shipping $\mathrm{CO}_{2}$ emissions. Expressions of forecast certainty in this environment are irrational but a well-presented alternative strategy might influence specialists' attitudes and eventually 
their behaviour. Trade associations, professional bodies and governments must work together to provide detailed examples of operational best practice, and regular briefings for practitioners to offer practical advice on measures to reduce emissions and operating costs, plan investments and implement technical measures to achieve emissions reductions. To enhance engagement with maritime professionals, an external agency or specialist group within IMO is required to promote monitoring and continuous improvements in standards beyond ship design and operational compliance.

Overall, panellists expected global tanker demand to 2050 to rise only modestly despite increasing demands to ship more water, avoid pirates and ECAs, and satiate rapidly developing economies. Demand offsets include shorter sea-routes via Arctic passages and upgraded canals, reducing haul lengths attributable to localised sourcing and more efficient ship operating plans to reduce carbon emissions, reducing oil intensity, and modal shifts to pipelines which present decision regulators for policy makers. Future work might investigate whether sudden unexpected supply disruptions, regulatory initiatives or technological developments might be required to reinforce changes in for example bunker costs and levies to influence shippers' margins sufficiently to stimulate this very conservative industry to embrace more radical emission reduction policies. Proactive policies are required to research the impact of re-routing, re-sourcing, mode shift and production upgrades on tanker emissions. Post-hoc, critical incident analysis of the behavioural impacts of dynamic supply, regulatory and technological developments on tanker movements is required to formulate optimal emissions reduction policies.

Perceptions of modest global change coupled with reducing energy intensities in advanced economies imply dramatic shifts in tanker market shares towards developing economies. Perceptions of accelerating global preferences for pipelines over maritime flows and increasing demand for nuclear power, combined with reducing tolerance of fossil fuels in energy production may signify systemic post-oil dependence behavioural shifts. However, evidence presented here implies that real behavioural change will require active policy driven statutory emissions reduction commitments rather than passive reliance on growing fossil fuel intolerance. Longer term, shifts in the economics of tanker movements may depend on unpredictable factors such as ice-strengthened hull availability, the incidence and political fall-out of oil spills incidents in Arctic waters, and the accessibility and cost of pipelines from Russia and MEG. The extent to which legislation or other regulatory measures will be required will depend on the effectiveness of carbon emission reduction targets. National or regional level interventions might include for example Emission Control Areas, port state controls or environmental and land use planning regulations around refineries. Findings that oil hauls lengthen if ships re-route to avoid ECAs and piracy underpin the need to coordinate international action through IMO and other UN agencies to find and address the root causes of piracy, and to minimise the number of failed states. Similarly, to be effective in cutting global rather than local emissions, ECA designations require agreements between adjacent regions and jurisdictions to minimise circumnavigation. Future oil tanker flows will vary, perhaps unpredictably, with regional growth rates, dynamic oil sourcing policies and socio-political drivers such as piracy. Future forecasts of tanker movements might intertwine with the formulation and evaluation of policy strategies to manage each.

\section{Acknowledgements}

The support of our research sponsors, the Research Councils UK (RCUK) Energy Programme and industry (in particular Lloyds Register), is gratefully acknowledged.

\section{References}

Alberts, D.J., 2007. Stakeholders or subject matter experts, who should be consulted? Energy Policy 35 (4), 2336-2346.

Aleklett, K., Höök, M., Jakobsson, K., Lardelli, M., Snowden, S., Söderbergh, B., 2010 The peak of the oil age-analyzing the world oil production reference scenario in world energy outlook 2008. Energy Policy 38 (3), 1398-1414.

BP, 2012. Statistical Review of World Energy June 2011 British Petroleum. 〈http:/ www.bp.com/statisticalreview $>$ (13 May 2013).

Buhaug, Ø., Corbett, J.J., Endresen, Ø., Eyring, V., Faber, J., Hanayama, S., Lee, D.S. Lee, D., Lindstad, H., Mjelde, A., Pålsson, C., Wanquing, W., Winebrake, J.J. Yoshida, K., 2009. Second IMO Greenhouse Gas Study. International Maritime Organization, London.

Cetin, C.R., Cerit, G., 2010. Organisational effectiveness at seaports: a systems approach. Maritime Policy and Management 37 (3), 195-219.

Committee on Climate Change, 2011. Review of UK Shipping Emissions. The Committee on Climate Change, London.

Czinkota, M.R., Ronkainen, I.A., 1997. International business and trade in the next decade: report from a Delphi study. Journal of International Business Studies 28 4), 827-844.

DECC, 2009. UK low carbon transition plan emissions projections URN 09D/678. Department of Energy and Climate Change, London.

DTi, 2007. Meeting the energy challenge: A White Paper on Energy. The Stationary Office, London.

Department of Energy and Climate Change, 2011. The Carbon Plan: Delivering our low Carbon Future. HM Government, London.

DfT, 2010. Maritime Statistics 2009 (annually). London: Department for Transport. Dinwoodie, J., Bhatia, R., 2004. Daily oil losses in shipping crude oil. Measuring crude oil loss rates in daily North Sea shipping operations. Energy Policy 32 (6) 811-822.

Dinwoodie, J. Morris, J. 2003. Tanker forward freight agreements: the future for freight futures? Maritime Policy and Management 30 (1), 45-58.

Dinwoodie, J., Tuck, S., Sanchez-Rodrigues, V., Mangan, J., 2011. Low carbon shipping: oil tanker movements involving the UK, IAME Annual conference, Santiago Chile, October.

Dukes, 2011. Digest of United Kingdom Energy Statistics, Annual. Department of Energy and Climate Change. The Stationary Office, London \$www.decc.gov.uk/en/ content/cms/statistics/publications/dukes/dukes.aspx〉. (20 September 2012).

EC, 2008. European energy and transport trends to 2030-update 2007 Luxembourg: European Commission Directorate-General, Office for Official Publications of the European Communities. 〈http://ec.europa.eu/dgs/ener gy transport/figures/trends 2030_update_2007/energy transport trends 2030_update_2007_en.pdf) 22 January 2011.

EIA, 2011. International Energy Outlook, Annual. Washington DC: Office of Integrated Analysis and Forecasting, Energy Information Administration, Department of Energy. 〈www.eia.doe.gov/oiaf/ieo/index.html〉 12 January 2011.

EM, 2012. The Outlook for Energy: A View to 2040. Irving, Texas, Exxon Mobil. www.exxonmobil.com〉 (28.08.13).

Fowkes, T., Preston, J., 1991. Novel approaches to forecasting the demand for new local rail services. Transportation Research A 25a (4), 209-218.

Gilbert, P., Bows, A., 2012. Exploring the scope for complementary sub-global policy to mitigate $\mathrm{CO}_{2}$ from shipping. Energy Policy 50 (11), 613-622.

Gilje, T., Dinwoodie, J., Challacombe, J., 2002. Crude carrier consolidation and capital cost. International Journal of Maritime Economics 4 (1), 35-54.

Glen, D.R., 2006. The modelling of dry bulk and tanker markets: a survey. Maritime Policy and Management 33 (5), 431-445.

Glen, D.R., Marlow, P., 2009. Maritime statistics: a new forum for practitioners Maritime Policy and Management 36 (2), 185-195.

Hammer. J., 2009. Long-term oil tanker demand. Managing Risk, 2. Oslo: Det Norske Veritas. 〈http://www.dnv.com/industry/maritime/publicationsanddownloads publications/dnvtankerupdate/2009/2_2009/Longtermoiltankerdemand.asp > 14 February 2011.

Her Majesty's Treasury, H.M., 2006. Stern Review: The Economics of Climate Change. London: HM Treasury. 〈http://webarchive.nationalarchives.gov.uk/ +/http://www.hm-treasury.gov.uk/stern_review report.htm〉13 January 2011.

Ho, J., 2010. The implications of Arctic sea ice decline on shipping. Marine Policy 34 (3), 713-715.

IMO, 2013. IMO. London, International Maritime Organisation. 〈http://www.imo. org $>20$ April 2013.

Korinek, J., Sourdin, P., 2009. Maritime Transport Costs and Their Impact on Trade. OECD paper, August. 〈http://www.etsg.org/ETSG2009/papers/korinek.pdf〉 10 January 2011.

LaBelle, M., 2012. Constructing post-carbon institutions: assessing EU carbon reduction efforts through an institutional risk governance approach. Energy Policy 40 (1), 390-403.

Landeta, J. 2006. Current validity of the Delphi method in social sciences. Technological Forecasting and Social Change 73 (5), 467-482.

Lindstad, H., Asbjørnslett, B.E., Strømman, A.H., 2011. Reductions in greenhouse gas emissions and cost by shipping at lower speed. Energy Policy 39 (3) 3456-3464.

Lindstad, H., Asbjørnslett, B.E., Strømman, A.H., 2012. The importance of economies of scale for reductions in greenhouse gas emissions from shipping. Energy Policy 46 (4), 386-398.

Linstone, A., Turoff, A., 1975. The Delphi Method: Techniques and Applications. Addison Wesley, Reading, MA. 
Lloyd's Register, 2013. Global Marine Trends 2030. Lloyd's Register Strategic Research, London and Singapore. 8th April. 〈www.lr.org/gmt2030〉20 April 2013.

MDS Transmodal Limited, 2007. Update of UK port demand forecast to 2030 and economic value of transhipment study. 〈http://www.dft.gov.uk/pgr/shipping ports/ports/portspolicyreview/207015_Final_Report_2.pdf 12 December 2010.

Makkonen, M., Pätäri, S., Jantunen, A., Viljainen, S., 2012. Competition in the European electricity markets-outcomes of a Delphi study. Energy Policy 44 (5), 431-440.

Makukha, K., Grey, R., 2004. Logistics partnerships between shippers and logistics service providers: the relevance of strategy. International Journal of Logistics: Research and Applications 7 (4), 361-377.

Mander, S., Walsh, C., Gilbert, P., Traut, M., Bows, A., 2012. Decarbonizing the UK energy system and the implications for UK shipping. Carbon Management 3 (6), 601-614.

Miola, A., Marra, M., Ciuffo, B., 2011. Designing a climate change policy for the international maritime transport sector: market-based measures and technological options for global and regional policy actions. Energy Policy 39 (9), 5490-5498.

Nakhle, C., 2007. Do high oil prices justify an increase in taxation in a mature oil province? The case of the UK continental shelf. Energy Policy 35 (8), 4305-4318.

Nowack, M., Endrikat, J., Guenther, E., 2011. Review of Delphi-based scenario studies: quality and design considerations. Technological Forecasting and Social Change 78 (9), 1603-1615.

Osler, D., 2010. Tomorrow's world. Lloyds List, 30 June.

Parsons, J., Dinwoodie, J., Roe, M., 2011. Northern opportunities: a strategic review of Canada's Arctic icebreaking services. Marine Policy 35 (4), 549-556.

Petersen, M.S., Enei, R., Hansen, C.O., Larrea, E., Obisco, O., Sessa, C., Timms, P.M., Ulied,A., 2009. Report on Transport Scenarios with a 20 and 40 year Horizon, Final report. Copenhagen: funded by DG TREN.
Piecyk, M.I., McKinnon, A.C., 2010. Forecasting the carbon footprint of road freight transport in 2020. International Journal of Production Economics 128 (1), 31-42.

Qu, M., Ahponen, P., Tahvanainen, L., Pelkonen, P., 2010. Chinese academic experts' assessment for forest bio-energy development in China. Energy Policy 38 (11), 6767-6775.

Saaty, T., Boone, L., 1990. Embracing the Future: Meeting the Challenge of our Changing World. Praeger, New York.

Schiffer, H-W., 2008. WEC energy policy scenarios to 2050. Energy Policy 36 (7), 2464-2470.

Shell, 2008. Shell Energy Scenarios to 2050. The Hague, the Netherlands, Shell International BV. 〈www.shell.com〉 (10.06.10).

Sorrell, S., Speirs, J., Bentley, R., Brandt, A., Miller, R., 2010. Global oil depletion: a review of the evidence. Energy Policy 38 (9), 5290-5295.

Stopford, M., 2009. Maritime Economics, 3rd Ed. Routledge, London.

Stott, P.W., Wright, P.N.H., 2012. The Panama Canal expansion: business as usual or game changer for ship design? Port Technology International 53, 27-28.

Tavana, M., Pirdashti, M., Kennedy, D.T., Belaud, J-P., Behzadian, M., 2012. A hybrid Delphi-SWOT paradigm for oil and gas pipeline strategic planning in Caspian Sea basin. Energy Policy 40 (1), 345-360.

UNCTAD, 2010. Oil Prices and Maritime Freight Rates: An Empirical Investigation. Technical report UNCTAD/DTL/TLB/2009/2. April, UNCTAD.

Verbruggen, A., Al Marchohi, M., 2010. Views on peak oil and its relation to climate change policy. Energy Policy 38 (10), 5572-5581.

Wang, C., Corbett, J.J., 2007. The costs and benefits of reducing $\mathrm{SO}_{2}$ emissions from ships in the US West Coastal waters. Transportation Research D 12 (8), 577-588.

von der Gracht, H.A., Darkow, I-L., 2010. Scenarios for the logistics services industry: a Delphi-based analysis for 2025. International Journal of Production Economics 127 (1), 46-59. 